\title{
Management of Tooth Discoloration after Orthognathic Surgery Complications: Report of Two Cases
}

\author{
Manejo de Pigmentaciones Dentarias por Complicaciones \\ en Cirugía Ortognática: Reporte de Dos Casos
}

\begin{abstract}
Lucas David Galvani; Hernán Coaguila-Llerena'; Ester Alves Ferreira Bordini²; Andréa Abi Rached Dantas ${ }^{1}$; Jose Roberto Cury Saad ${ }^{1}$ \& Milton Carlos Kuga ${ }^{1}$
\end{abstract}

GALVANI, L. D.; COAGUILA-LLERENA, H.; BORDINI, E. A. F.; DANTAS, A. A. R.; SAAD, J. R. C. \& KUGA, M. C. Management of tooth discoloration after orthognathic surgery complications: report of two cases. Int. J. Odontostomat., 15(3):553-557, 2021.

ABSTRACT: Orthognathic surgery is performed for the correction of craniofacial discrepancies. However, complications, such as tooth discoloration are possible. This case report presents two patients who underwent bilateral sagittal split ramus osteotomy associated with segmental Le Fort I osteotomy and genioplasty. During surgeries, the apical region of anterior teeth was accidentally injured in both cases. After three-week surgery follow-up, the injured teeth showed a change in color to dark pink. In both teeth, the root canal treatment was performed followed by the non vital tooth bleaching. Three sessions were necessary to achieve a significant color change of the teeth. The two-year follow-up showed that both teeth preserved an acceptable color. It was concluded that tooth discoloration after orthognathic surgery is a possible complication, which could be overcome following a conservative approach. Additionally, patients should be informed preoperatively.

KEY WORDS:endodontics, orthognathic surgery, tooth bleaching, tooth discoloration.

\section{INTRODUCTION}

Orthognathic surgery is used to correct congenital and acquired dentofacial discrepancies with various implications regarding masticatory function, facial pain and aesthetics (Friscia et al., 2017). An interdisciplinary management that includes an orthodontic-surgical planning and monitoring is required (Espeland et al., 2008). Among surgical techniques, bilateral sagittal split ramus osteotomy in association or not with Le Fort I maxillary osteotomy is commonly used (Friscia et al.). The bilateral sagittal split ramus osteotomy is performed through a bilateral intraoral incision in the mandible, creating a fracture that allows mandibular movement, while the Le Fort I osteotomy aims to expose the maxilla, for a subsequent movement to the planned position (Sousa \& Turrini, 2012). A variation of Le Fort I osteotomy is the segmental Le Fort I osteotomy, which is useful for the treatment of transverse and vertical jaw discrepancies, such as anterior open bite (Ho et al., 2011). This technique offers good stability (Bauer \& Ochs, 2014). The combined maxillary and mandibular orthognathic surgery with counterclockwise rotation of the maxillo-mandibular complex is indicated in patients with long-face pattern, who usually have an altered respiratory pattern with sleep disorders, such as snoring, daytime fatigue, and apnea (Esteves et al., 2014).

The multiple steps, tissue planes and instrumentation involved in any orthognathic surgery are associated to possible complications, including dental injury (Naran et al., 2018), which may affect the pulp vasculature, resulting in bleeding and subsequent tooth discoloration (Marin et al., 1997). It has been demonstrated that there is a strong relationship between changes in pulpal blood flow and orthognathic surgery (Emshoff et al., 2000; Eroglu \& Sabuncuoglu, 2014).

\footnotetext{
${ }^{1}$ Department of Restorative Dentistry, Araraquara School of Dentistry, São Paulo State University - UNESP, Araraquara, 14801-903 SP, Brazil. ${ }^{2}$ Department of Physiology and Pathology, Araraquara School of Dentistry, São Paulo State University - UNESP, Araraquara, 14801-903 SP, Brazil.
} 
The available literature for this type of complication is very scarce. This case report presents two patients who showed tooth discoloration associated with orthognathic surgery complications and the conservative approach for the management.

\section{CASE REPORT}

Case 1. A 38-year-old male patient without systemic diseases was evaluated at maxillo-facial surgery department referred from the orthodontist. Previously, the patient had been intermittently under orthodontic treatment for eight years. Clinical examination revealed a long face pattern, anterior open bite, incompetent labial closure, vertical maxillary deficiency, decreased Wilson's curve and Angle's class III. The recommended treatment was orthognathic surgery for dental and cephalometric correction, which included the bilateral sagittal split ramus osteotomy, segmental Le Fort I osteotomy and genioplasty. The segmental Le Fort I osteotomy was performed between the maxillary lateral incisors and canines to separate the maxilla in three segments, posterior right, posterior left and anterior. During surgical procedures, the drill accidentally reached the apical region of the tooth 22 . The surgeon, aware of the complication, continued the surgery and later informed the referring dentist about what happened.
After three-week follow-up, the tooth showed a dark pink discoloration, so it was recommended the root canal treatment and further dental bleaching. During the access cavity, coagulated blood was observed in the pulp chamber. The root canal treatment was performed with ProTaper rotary files (Dentsply Sirona, Ballaigues, Switzerland) up to file F4 following the manufacturer's recommendations. Between each file, the canal was irrigated with $5 \mathrm{~mL}$ of $2.5 \%$ sodium hypochlorite using a $27 \mathrm{G}$ sidevented needle (Endo-Eze Irrigator Tips, Ultradent Products, South Jordan, UT, USA). The final irrigation was performed with $17 \%$ ethylene diamine tetraacetic acid - EDTA (Biodinâmica, Ibiporã, PR, Brazil) for 1 minute, and with $5 \mathrm{~mL}$ of $2.5 \%$ sodium hypochlorite. Then, the root canal was dried with paper points and obturated with gutta-percha points and AHPlus sealer (Dentsply Sirona) using the continuous wave technique.

After a week, the non vital tooth bleaching was performed by using Whiteness Super-Endo kit (FGM ProdutosOdontológicos, Joinville, SC, Brazil), a 37 $\%$ carbamide peroxide-based bleaching agent. The temporary restoration and the gutta-percha were removed up to 1-2 $\mathrm{mm}$ below the cement-enamel junction. An approximately $2 \mathrm{~mm}$ layer of glass ionomer cement (Ketac Molar, 3M ESPE, St. Paul, MN, USA) was placed to avoid contact of the bleaching gel with the gutta-percha. The excess of bleaching gel was removed with a sterile cotton pellet and the tooth was provisionally restored. The
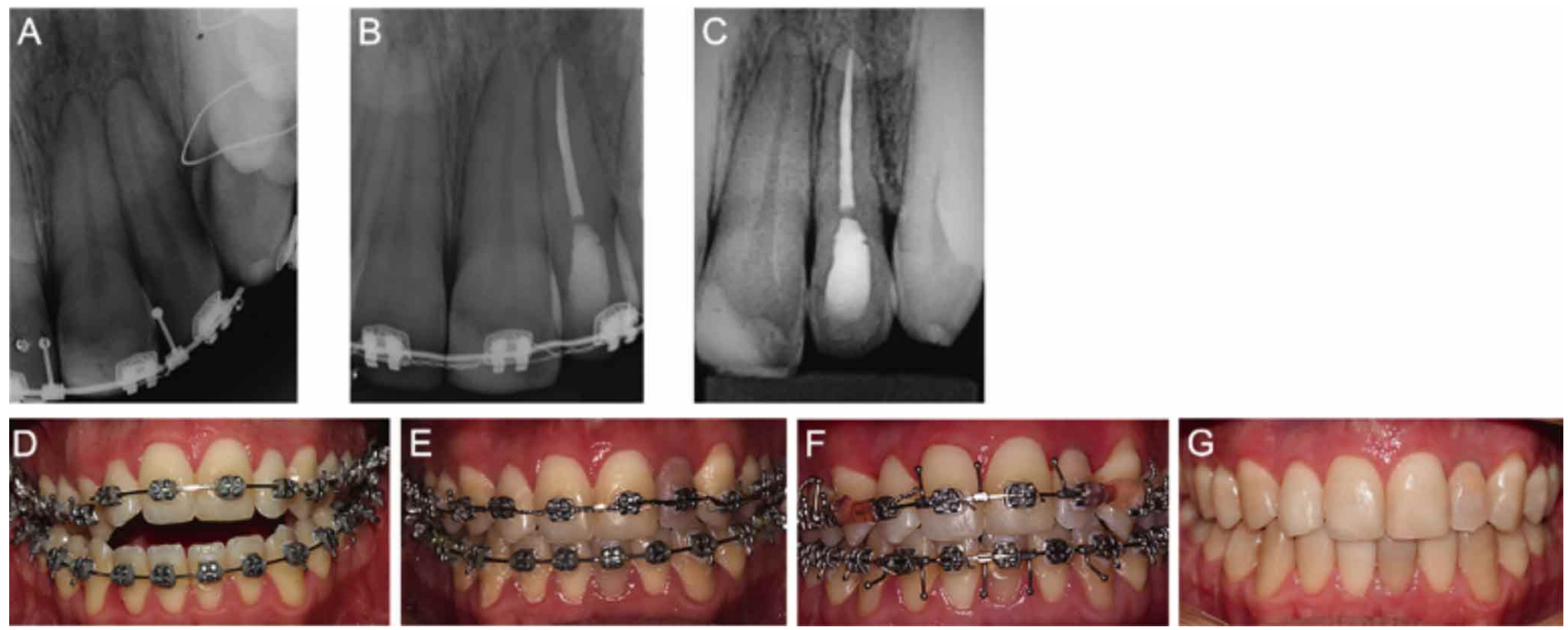

Fig. 1. Radiographic (A-C) and clinical (D-G) evolution of case 1. During orthognathic surgery, the apical region of the tooth 22was reached (A). Radiographic appearance after root canal treatment and nonvital tooth bleaching (B), and after two-year follow-up (C). The patient was under orthodontic treatment (D), and the effects of non vital tooth bleaching during this phase $(E, F)$ were visible. Clinical appearance after two-year follow-up (G). 
follow-up was every five days after the first application. Three sessions were required to reach a significant color change. The final restoration was performed two weeks after the last application of the bleaching gel. The two-year follow-up showed a slight color regression and no external invasive resorption (Fig. 1).

Case 2. A 57-year-old female patient without systemic diseases was evaluated at maxillo-facial surgery department referred from the orthodontist. The patient had a history of sleep apnea that was not possible to treat with less invasive methods. Clinical examination revealed a long face pattern. The recommended treatment was the counterclockwise rotation of the maxillo-mandibular complex to increase the airway space, so the bilateral sagittal split ramus osteotomy, in association with segmental Le Fort I osteotomy and genioplasty was planned.

During fixation of the anterior segment of the maxilla, one of the screws was placed in close proximity to apical region of the tooth 21 . After the complication,the screw was removed and placed in an appropriate position. The tooth discoloration was observed after three-week follow-up. The root canal treatment was performed in a single session using the Pro Taper rotary system (Dentsply Sirona) up to file F5. The irrigation and root canal filling procedures were the same as in case 1. After a week, the nonvital tooth bleaching was performed by using the Whiteness Super-Endo kit (FGM). In the same way as in case 1 , three sessions were necessary every five days to obtain a significant color change. The final restoration was performed two weeks after the last application of the bleaching gel. The two-year follow-up showed a slight color regression and no external invasive resorption (Fig. 2).

\section{DISCUSSION}

The aesthetics of teeth and their color is an important subject for patients, since it is directly represented in the enhancement of their smiles (Joiner \& Luo, 2017). Any discoloration causes aesthetic problems, so it is expected to execute the necessary efforts (Ahmed \& Abbott, 2012). This report of two cases showed discolored teeth after complications during orthognathic surgery.

When any orthognathic surgery procedure is performed without complications, there is usually no
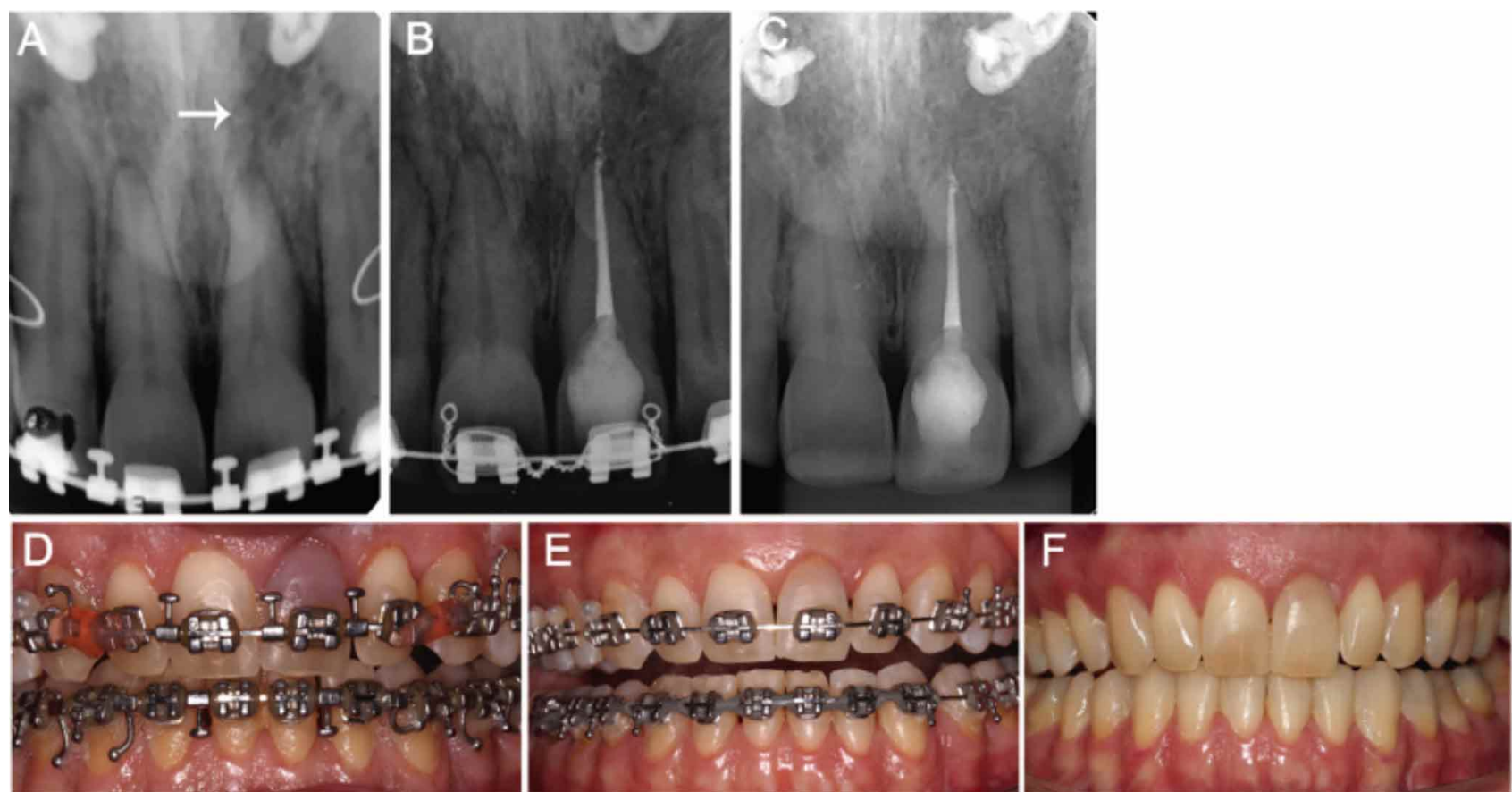

Fig. 2. Radiographic (A-C) and clinical (D-E) evolution of case 2. During orthognathic surgery, one of the screws was placed in close proximity to the tooth 21 , then, it was removed and placed in an appropriate position. The radiolucent trace of the screw was evident-arrow(A). Radiographic appearance after root canal treatment and nonvital tooth bleaching (B), and after two-year follow-up (C). The patient was under orthodontic treatment, and the effects of nonvital tooth bleaching during this phase $(D, E)$ were visible. Clinical appearance after two-year follow-up (F). 
risk of injury of the blood supply to the dentition (Mesgarzadeh et al., 2010); however, the risk of discoloration is possible (Lee et al., 2016). Regarding this, a previous study showed that after a bilateral sagittal split ramus osteotomy associated with Le Fort I osteotomy, maxillary teeth are more vulnerable to discoloration than mandibular teeth, and the maxillary anterior teeth are the most affected (Lee et al.), as in the present case report. After orthognathic surgery there may be an initial tooth discoloration, which usually returns to normal coloration and response to pulp sensitivity tests (Robl et al., 2014). This is in contrast with a study that reported that no discolored teeth responded to electrical sensitivity tests; in fact, they observed that all the discolored teeth showed pulpal necrosis (Lee et al.).

The transient reversible vascular ischemia of the dental pulp and direct lesion of the dental apices are potential factors that result in pathological pulpal changes (Mesgarzadeh et al.). A study reported that segmental Le Fort I osteotomy could affect the blood supply to the maxilla and may produce tooth discoloration, as well as decreased vitality of anterior teeth (Emshoff et al.). In the present case report, the injury of the apical region in both teeth was by the drill and the screw in case 1 and 2, respectively, which caused an evident neurovascular supply disruption. It is important to emphasize that the proximity to interdental cuts or the screws of the bone plates predispose to dental injury, and particularly to pulpal necrosis (Ho et al.). The incidence of dental injury in patients undergoing double-jaw surgery that included genioplasty was $5 \%$ (Friscia et al.). On the other hand, in a study where only segmental Le Fort I osteotomy was performed in maxillary teeth was 4 $\%$ (Ho et al.). It is important to note that genioplasty is directly related to the risk in mandibular teeth (Lee et al.).

Both cases showed dark pink teeth after threeweek surgery follow-up. The discoloration may be present in infected or uninfected teeth, in which the initial pink-colored change is followed by hemolysis of red blood cells (Watts \& Addy, 2001; Plotino et al., 2008). In the case of infected teeth, the interaction of heme with putrefying pulpal tissues releases iron, which interacts with sulfates produced by bacteria, eventually forming dark-colored iron sulfates, which discolor the gray tooth (Watts \& Addy). However, in the absence of infection, the release of iron is an unlikely event, because there are no reactions caused by bacterial byproducts (Plotino et al.). The aseptic conditions of the operative field during the orthognathic surgery allowed a tooth discoloration in the absence of infection, and this could explain the change in coloration that did not become gray.

It has been previously reported that seven days are sufficient for the elimination of residual oxygen of bleaching agent from tooth structure, which could damage the adhesion of the composite resin (Barkhordar et al., 1997). Additionally, it has been demonstrated that at three weeks, an optimum adhesion to the enamel can be obtained (Shinohara et al., 2001). In this report, the final restorations were performed two weeks after the last application of the bleaching agent, an intermediate period. It is important to consider that the bleaching agent has a critical influence on the prognosis of non vital tooth bleaching. Regarding this, it was reported the association of $30 \%$ hydrogen peroxide and sodium perborate (Barkhordar et al.), and sodium perborate and $37 \%$ carbamide peroxide (Shinohara et al.). The association of $30 \%$ hydrogen peroxide and sodium perborate causes greater microfiltration than $37 \%$ carbamide peroxide, probably due to the slow release of hydrogen peroxide through enamel and dentin (Teixeira et al., 2003). In this report, the bleaching agent was $37 \%$ carbamide peroxide based, so theoretically the final restoration could have been performed even on the 7th day. After two-year followup the teeth showed a slight color regression in both patients. Although the non vital tooth bleaching technique is safe and predictable, a slight color change has been reportedup to five-year follow-up; however, it was considered as "good" or "acceptable"for both operator and patient (Abbott \& Heah, 2009). Another study (Pedrollo Lise et al., 2018) also showed a color regression after non vital tooth bleaching, which remained stable after one year. Therefore, the protocol followed by this report of two cases showed an encouraging result, considering the elapsed time.

\section{CONCLUSION}

Patients should be informed before the orthognathic surgery about possible post-operative complications including the possibility of tooth discoloration. This kind of complication could be managed by a conservative approach, which includes root canal treatment and non-vital tooth bleaching. 


\section{ACKNOWLEDGMENTS}

Coordenação de Aperfeiçoamento de Pessoal de Nível Superior - Brasil (CAPES) - FinanceCode 001.

GALVANI, L. D.; COAGUILA-LLERENA, H.; BORDINI, E. A. F.; DANTAS, A. A. R.; SAAD, J. R. C. \& KUGA, M. C. Manejo de pigmentaciones dentarias por complicaciones en cirugía ortognática: reporte de dos casos). Int. J. Odontostomat., 15(3):553-557, 2021.

RESUMEN: La cirugía ortognática es comúnmente realizada para corregir las discrepancias cráneo-faciales. Sin embargo, se pueden producir complicaciones tales como la pigmentación dentaria. Este reporte de casos presenta a dos pacientes que fueron sometidos osteotomía sagital bilateral de la rama mandibular asociada a osteotomía segmentaria Le Fort I y genioplastía. Durante la fase quirúrgica, la región apical de dientes anteriores fueron accidentalmente dañados en ambos casos. Después de tres semanas de seguimiento de la cirugía, los dientes afectados mostraron un cambio de color a rosado oscuro. Se realizó el tratamiento de conductos seguido de aclaramiento interno en ambas piezas dentarias. Fueron necesarias tres sesiones para lograr un cambio de color significativo. El seguimiento de dos años mostró que ambos dientess conservaron un color aceptable. En conclusión, la pigmentación dentaria después de la cirugía ortognática es una posible complicación, sin embargo, puede ser tratada por medio de un enfoque conservador. Además, los pacientes deben ser informados antes de la cirugía.

PALABRAS CLAVE: blanqueamiento de dientes, cirugía ortognática, decoloración de dientes, endodoncia.

\section{REFERENCES}

Abbott, P. \& Heah, S. Internal bleaching of teeth: an analysis of 255 teeth. Aust. Dent. J., 54(4):326-33, 2009.

Ahmed, H. M. A. \& Abbott, P. V. Discolouration potential of endodontic procedures and materials: a review. Int. Endod. J., 45(10):88397, 2012.

Barkhordar, R. A.; Kempler, D. \& Plesh, O. Effect of nonvital tooth bleaching on microleakage of resin composite restorations. Quintessence Int., 28(5):341-4, 1997.

Bauer, R. E. \& Ochs, M. W. Maxillary orthognathic surgery. Oral Maxillofac. Surg. Clin. North Am., 26(4):523-37, 2014.

Emshoff, R.; Kranewitter, R.; Gerhard, S.; Norer, B. \& Hell, B. Effect of segmental Le Fort I osteotomy on maxillary tooth type related pulpal blood-flow characteristics. Oral Surg. Oral Med. Oral Pathol. Oral Radiol. Endod., 89(6):749-52, 2000.

Eroglu, S. E. \& Sabuncuoglu, F. A. Changes in dental pulp blood flow of different maxillary tooth types after Le Fort I osteotomy. J. Craniofac. Surg., 25(5):e420-4, 2014.
Espeland, L.; Hogevold, H. E. \& Stenvik, A. A 3-year patient-centred follow-up of 516 consecutively treated orthognathic surgery patients. Eur. J. Orthod., 30(1):24-30, 2008.

Esteves, L. S.; Castro, V.; Prado, R.; de Moraes e Silva, C. Á. V.; do Prado, C. J. \& Trindade Neto, A. I. Assessment of skeletal stability after counterclockwise rotation of the maxillomandibular complex in patients with long-face pattern subjected to orthognathic surgery. J. Craniofac. Surg., 25(2):432-6, 2014.

Friscia, M.; Sbordone, C.; Petrocelli, M.; Vaira, L.A.; Attanasi, F.; Cassandro, F.M.; Paternoster, M.; laconetta, G. \& Califano, L. Complications after orthognathic surgery: our experience on 423 cases. Oral Maxillofac. Surg., 21(2):171-7, 2017.

Ho, M. W.; Boyle, M. A.; Cooper, J. C.; Dodd, M. D. \& Richardson, D. Surgical complications of segmental Le Fort I osteotomy. Br. J. Oral Maxillofac. Surg., 49(7):562-6, 2011.

Joiner, A. \& Luo, W. Tooth colour and whiteness: a review. J. Dent., 67:S3-S10, 2017.

Lee, U. L.; Lee, E. J.; Seo, H. Y.; Han, S. H.; Choi, W. C. \& Choi, Y. J. Prevalence and risk factors of tooth discolouration after orthognathic surgery: a retrospective study of 1455 patients. Int. J. Oral Maxillofac. Surg., 45(11):1464-70, 2016.

Marin, P. D.; Bartold, P. M. \& Heithersay, G. S. Tooth discoloration by blood: an in vitro histochemical study. Dent. Traumatol., 13(3):132-8, 1997.

Mesgarzadeh, A.; Motamedi, M. H. K.; Akhavan, H.; Tousi, T. S.; Mehrvarzfar, P. \& Eshkevari, P. S. Effects of Le Fort I osteotomy on maxillary anterior teeth: a 5-year follow up of 42 cases. Eplasty, 10:e10, 2010.

Naran, S.; Steinbacher, D. M. \& Taylor, J. A. Current concepts in orthognathic surgery. Plast. Reconstr. Surg., 141(6):925e-936e, 2018.

Pedrollo Lise, D.; Siedschlag, G.; Bernardon, J. K. \& Baratieri, L. N. Randomized clinical trial of 2 nonvital tooth bleaching techniques: A 1-year follow-up. J. Prosthet. Dent., 119(1):53-9, 2018.

Plotino, G.; Buono, L.; Grande, N. M.; Pameijer, C. H. \& Somma, F. Nonvital tooth bleaching: a review of the literature and clinical procedures. J. Endod., 34(4):394-407, 2008.

Robl, M. T.; Farrell, B. B. \& Tucker, M. R. Complications in orthognathic surgery. Oral Maxillofac. Surg. Clin. North Am., 26(4):599-609, 2014

Shinohara, M. S.; Rodrigues, J. A. \& Pimenta, L. A. In vitro microleakage of composite restorations after nonvital bleaching. Quintessence Int., 32(5):413-7, 2001.

Sousa, C. S. \& Turrini, R. N. T. Complications in orthognathic surgery: a comprehensive review. J. Oral Maxillofac. Surg. Med. Pathol., 24(2):67-74, 2012.

Teixeira, E. C. N.; Hara, A. T.; Turssi, C. P. \& Serra, M. C. Effect of non-vital tooth bleaching on microleakage of coronal access restorations. J. Oral Rehabil., 30(11):1123-7, 2003.

Watts, A. \& Addy, M. Tooth discolouration and staining: a review of the literature. Br. Dent. J., 190(6):309-16, 2001.

Corresponding author:

Milton Carlos Kuga

RuaHumaitá 1680, Araraquara

14801-903 SP

BRAZIL

E-mail: kuga@foar.unesp.br 